\title{
More Personal Reflections on Life Part III
}

\author{
The Launch of a Journey Lasting 65 Years: Personal \\ Observations Made From a Front-Row Seat at the \\ Greatest Show on Earth
}

\author{
Henry J.M. Barnett
}

Can. J. Neurol. Sci. 2010; 37: 160-166

Two parts of my recollections have been published. The first relates to my early days, how I found myself in Medical School. ${ }^{1}$ The second is a summary of what research I found myself pursuing. ${ }^{2}$ In brief summary of my research pursuits, my earliest novel scientific contribution involved the identification with $\mathrm{Al}$ Jousse of post-traumatic syringomyelia ${ }^{3}$ and then the revelation that there was a fifth recognizable variety of syringomyelia. All but the type associated with spinal cord tumors depend on the subarachnoid space for its supply of intra-syringal fluid and does not arise from any ventricular communication. ${ }^{4}$

Later my interest shifted to stroke neurology and I had the good fortune in consort with Fraser Mustard to establish for the first time and with reasonable certainty that aspirin as a platelet inhibitor could prevent ischemic stroke..$^{5,6}$

Data from clinical trials demands careful patient scrutiny and critical review of all of their investigative studies. This resulted in two new causes of stroke being identified. First was the fact that cerebral ischemic events were occasionally caused by emboli from ulcerative lesions on prolapsing mitral valves. ${ }^{7}$ The report of our series was much debated because cardiologists regarded the lesion readily found by echocardiography as rather common and many had not noted cerebral complications. In time pathologists and surgeons reported on the offending lesion with attached thrombi and the doubt diminished. Finally a Mayo Clinic group was able to confirm our epidemiological study. ${ }^{8}$ Prolapsing mitral valves is now recognized as an occasional cause of cerebral ischemia and one to be sought when commoner causes are not identifiable.

The second recognized cause of stroke came from our observation that ischemic events may persist despite arterial (in this case carotid) occlusion. ${ }^{9}$ The stump of an occluded artery may persist and angiography allows recognition within it of loose thrombotic material. With neuropathologist John Kaufmann we recorded the details and pathological findings in a small series of what we called The Stump Syndrome. ${ }^{10}$ A few were dealt with by surgical "stumpectomy" or stump ligation. The stroke complication rate was too high and in time we recommended albeit emperically only anti thrombotic therapy.

Thirty years, the last of my practice life were now devoted to evaluating the role of surgery in stroke prevention: Cerebral bypass anastomoses were shown not to be effective ${ }^{11}$; symptomatic carotid stenosis in the range of $70-95 \%$ is the prime indication for carotid endarterectomy (CE) for men and women as reported in the "severe" phase of the NASCET study. ${ }^{12}$ Muted but definite benefit is found in patients with near-occlusion ${ }^{13}$ and when the stenosis is $50-69 \%$ (moderate) ${ }^{14}$. But in women it requires other risk factors ${ }^{15}$. Patients with ocular symptoms alone also require other risk factors or they will not benefit. ${ }^{16}$ Symptomatic elderly males free of other organ failure are exceptionally good candidates for CE, enjoying the highest risk/ benefit ratio. ${ }^{17}$ In symptomatic stenosis, the stroke risk rises proportionately with the degree of stenosis. This is in contradistinction to the asymptomatic trials where the measurements were made from ultrasound alone. In them the risk did not rise as the calculated degree of stenosis increased. ${ }^{18,19}$ Carotid endarterectomy is not helpful and may be harmful if the stenosis is $50 \%$ or less. All NASCET's conclusions are based on angiographic measurement of stenosis by Fox' method ${ }^{20,21}$ and based on surgical expertise that allows of operative complications of stroke and death not exceeding 6$7 \%$. If the 30-day independently audited risk of operative stroke and death for a given institution exceeds $7 \%$ the risk profile for the threat of stroke for the individual patient must include carotid endarterectomy. Attempts to strengthen our observations by pooling data with other studies were made but have been largely disappointing. ${ }^{22}$ There are too many dissimilarities in protocol design (including allowing "surgical discretion" to determine which patients should be randomized), rigor in confirming entry criteria and outcomes, definitions, review of all films by expert neuroradiologists, funding for confirmatory studies, and operative complications. Similarly I have become uneasy about the common practice of seeking to refine the truth by metaanalyses. Quantity, if anything, detracts from quality.

Received September 25, 2009. Final Revisions Submitted October 9, 2009. Correspondence to: Henry J.M. Barnett, (Professor Emeritus, University of Western Ontario), 14865 Concession 7, King City, Ontario, L7B 1K4, Canada. 
A summary of my reflections on surgical measures to prevent stroke has been published recently. ${ }^{22}$ Endarterectomy is a procedure that will never be free of stroke risk and should be performed only by experts or under experts' supervision. There is no existing proof that CE should be offered to asymptomatic persons. Nor is there convincing proof that angioplasty and stenting are safer and more durable than CE.

The conduct over several decades of a substantial number of well-funded randomized multicentre trials illuminated for me the importance of serious interdisciplinary collaboration to achieve the goal of a scrupulous data-base. Without this the analyses are questionable and readily misleading. Guidelines for those who would enter into this complex area of clinical research have been composed with the collaboration of one of my principal study managers and published. ${ }^{23}$ Of special importance is to note that the sample size is best determined by calculating the number of outcomes expected and to put less emphasis on the randomized number. An early and searching review at the participating centre and by the Central Office of all details of every reported outcome is a sine qua non of credibility.

The current addition to my medical life's story relates to particular people, places and events that stood out and were observed from my front-row seat in the 65 years since I graduated in 1944. There will be no strict temporal ordering of these observations, appearing as numbered "anecdotes".

\section{Anecdote 1}

Post-graduate colleagues and some of one's outstanding teachers have the greatest permanent impact. My early and ultimate training in Neurology was in Toronto largely as resident/fellow with $\mathrm{HH}$ Hyland and with minor contact only with JC Richardson, with whom I never established rapport. My post-graduate training by Toronto tradition was in the UK (Queen Square) followed by four months at the Radcliffe Infirmary in Oxford with Ritchie Russell and Sir Hugh Cairns. In London I bonded particularly with: that master of neurology, Sir Charles Symonds; with Greenfield, the great neuro-pathologist; with fellow-Torontonian, Oscar Kofman; and from Newcastle, John Walton. As John and I were getting ready to part at the end of these exciting days I enquired of his future: "I intend to concentrate on muscle disease." "Why bother, there is not much any one can do about those congenital disorders?", "All the more reason for looking at them! What is your long-term plan?", "I will follow stroke". With a smile: "Your thinking is inconsistent." Within a decade Walton had become the major recipient of the early research funds gathered with the great push by the firefighters of the USA for the American Muscular Dystrophy Association (in those early days little US research was going on in this field). Within a few years he had emerged as the world's top authority in muscle disease, had added Newcastle to the top list of the world's leading neurological centres and had published the first of many editions of the definitive volume of his magnum opus "Disorders of Voluntary Muscle". Within another decade, along with Mohr, Stein and Yatsu we had launched through the same publisher, our encyclopedic book on "Stroke: Pathophysiology, Diagnosis and Treatment." By the time this book reached its 5th edition both prevention and post-stroke therapy were considerably advanced as compared to the neglect, verging on dislike, accorded this

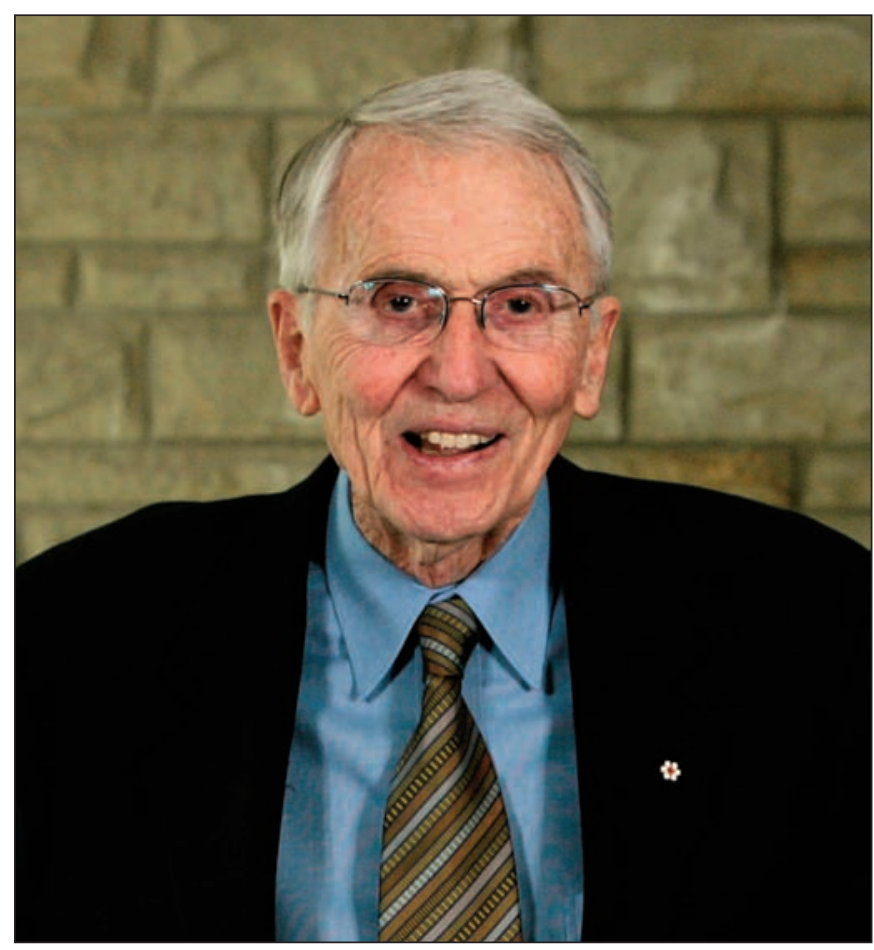

Figure 1: HJM Barnett, author of memoirs. 2008.

disorder when I entered medicine. The Chinese, where stroke is common, had copied our entire first edition without permission. The new cover of the plagiarized volume was not blue but symbolically bright red. I have a copy that was presented to me in Beijing.

John, in due course and by enormous dedication, advanced to the House of Lords and as Lord Walton of Detchant, was involved as a major contributor to the Stem-cell Committee of the Upper House, helping his country plan its sensible approach to stem-cell research. In their conclusions a life-time of horrible disability was no longer allowed to be trumped by religious zealotry.

Oscar Kofman became one of the first Canadians to study dopaminergic drugs with Hornykiewicz and Barbeau. Later and most importantly he conducted the definitive studies that led to our understanding of the toxic effects of industrial waste products containing mercury in aboriginal populations dependent on the fish populations. Today the pulp industry has become more responsible and when waters are accidentally contaminated or remain toxic they are posted. Minamata Bay disasters have been avoided.

\section{Anecdote 2}

My teenage passion for natural things has never relaxed its grip on me. Today March 20 as I sit at my computer, I am hearing the strident calls of red-shouldered hawks (a species just removed from the "critical list") which have returned from southern USA to my forest overnight. Mostly it has returned in this very week since 1960, and, for all anyone knows, for 
centuries before then, when the Algonquins and Hurons were portaging the Toronto Carrying Place through this forest. These hawks need a minimum of 100 acres of undisturbed hardwood forest in which to nest and raise their young. In conjunction with my neighbors and the Nature Conservancy of Canada we have added 300 more acres of good forest to the 110 eased to preservation by me and my adjacent neighbor, Ron Tasker, hoping to ensure their permanent survival. What has this to do with my teachers? As I was leaving Queen Square Sir Charles said he had just heard I was keen on birds. On week-ends it appears we both exchanged reflex hammers for binoculars. On several visits he made to Toronto in the years ahead we visited my favorite haunts in the region including swamps and sewage lagoons, and he quickly proved to be as apt a pupil of ornithology as he had been of neurological lore. A margin of mature conifers grows at the edge of my forest where he and I and a few residents had planted seedlings. Meanwhile he had marveled at wood ducks (our most highly colored waterfowl) carrying nesting material into a hollow in a nearby tree overhanging the pond. Lord Walton but also Lord Brain were keen bird-watchers. One day Brain gave a formal lecture at University of Toronto and I picked him up after his lecture to go to a big marsh outside Oshawa. This was the only place where I felt certain that I could fulfill his wish to observe that archskulker the Least Bittern. Russell was dressed in the formal clothing of a guest lecturer, including polished black shoes, striped black pants, dark jacket and vest. He was an interesting sight with two items dangling across his chest: an old-fashioned gold watch chain and a pair of binoculars. We found the Least Bittern sitting on its nest in the cat-tails deep in the swamp. His zeal to observe these rarities left him getting on his transatlantic plane with wet and non-shining black shoes and pants wet to above the ankles. We managed to wipe off the mud. We had time to discuss and for me to marvel at his first identification of the carpal tunnel syndrome, so obvious now after his initial descriptions based on critical observation conducted on scores of patients with numb and maybe painful and wasted hands. The zenith of descriptive neurology, a 19th and early 20th century characteristic of the British and French was reached by Brain and those about him at that period in London. Neurological problemsolving requires the development deliberately (or instinctively) of pattern recognition, coupled with careful history-taking, meticulous physical examination and a knowledge of neuroanatomy.

\section{Anecdote 3}

Everything about the early part of that particular day in 1963 was unexceptional. I ate my fried egg sandwich as usual at 6:00 am driving from my home to park at the Toronto General Hospital (TGH). I met my residents at the Nursing Station of the neurology floor at 6:30 am and did walk-about rounds. The medical students were added at 10:00 am and we all headed back around to show them the more instructive patients. We re-entered a room where at dawn rounds a calm lady with a syrinx had been abed. We met big change! She and the person in the next bed were sobbing and dabbing at the tears in their red eyes. And that was the exact time and place where I fixed forever in my memory bank that President Kennedy had been shot.

\section{Anecdote 4}

One day in May of 1945, I was walking along College Street in a white lab coat going from the Bunting Institute to the TGH. A respectably dressed man (business suit, vest and tie) who had just parked his car beside the road, leaped out of his car and proceeded to give me a hug! As he did this many car horns began to honk and he fairly shouted at me: "Sir, it's all over!" "What is over?" "The war of course. My car radio just announced that the Japanese are going to surrender today". We smiled and shook hands as total strangers, both equally elated. I mused later about whether or not he told his wife that night that he had hugged a white-coated stranger. The sentiments felt that day in Nagasaki must have been totally different. That night I heard on the radio that the Canadian 5th (Pacific) Division was to be disbanded at once and I took its badge off the upper arm of my RCAMC uniform. Two weeks later Army Orders disallowed my two-week old promotion from Captain to Major.

\section{Anecdote 5}

A year before the last shot was fired or the second nuclear bomb dropped, a young graduate nurse in her starched uniform and cap (with a new black band) came rushing into the alreadycrowded Nursing Station on Ward C and fairly shouted her message to those sitting quietly and attentively listening to change-of-shift rounds: "the Americans led by Ernest Hemingway have entered Paris and accepted its surrender intact." Liberty for the rest of France and Europe, including Canada's role in freeing Holland, was in sight. For our excited informant peaceful nights of slumber were one step closer. Her husband was a fighter-pilot in the RCAF. A few months later she proudly presented him in uniform including the diagonal-striped ribbon of the Distinguished Flying Cross to Ward C Staff. Like my young brother Victor his luck held out to the end and he did not go down in flames. As he put it laconically: "We did miss a piece of tail one night."

\section{Anecdote 6}

Forty night flights in Lancaster bombers over the Ruhr Valley occupied young brother Victor for most of three years. His worst memory was the night they were hit, the tail-gunner killed and all navigation equipment disabled. As navigator he directed the pilot to keep his right wing-tip aligned to the North Star and by handcompass and watch arrived at base in England only a half hour late. His service gave him permanent membership in the Royal Airforce Club where I stayed with him on the night of the World Series game that was won by the Blue Jays. Victor stayed to the end and in the morning had a "No Disturb" sign on his door. I enquired in several places as to the winner (The Club Concierge, breakfast waiter, Heathrow British Airways and Air Canada desks and ElAl crew). "Never heard of it" "World Series of what?" A shout from Don Easton greeted me in the baggage room of the Tel Aviv airport: "We'll get you guys next year."

I recall this first visit to Israel as jolly. It was apparent, though, that the Arabs of Israel were treated as second-class citizens: license plates of a distinctive color, no offers of replacement or compensation for their former Palestine dwellings, drivers of garbage trucks, not welcome in our hotel strip, sweepers of the streets. Natan Bornstein, a straightforward 


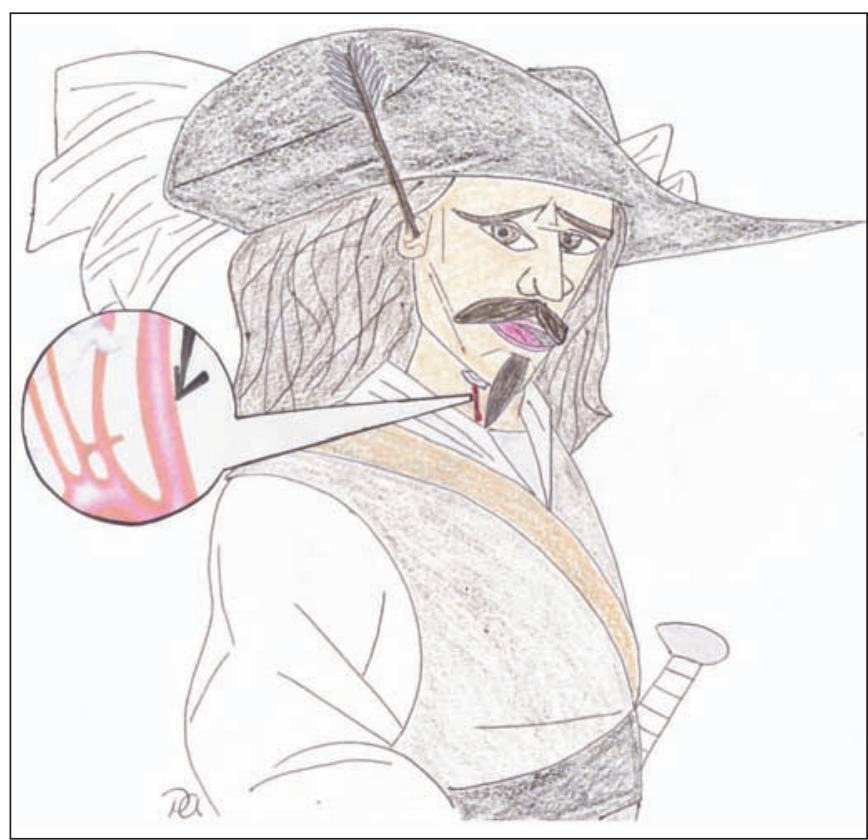

Figure 2: Cartoon of Samuel Champlain with stone-tipped Iroquois arrow through ear, grazing cheek and just missing carotid artery. From "The Works of Samuel de Champlain", Vol II, Reproduced 1925. Page 129, Toronto, The Champlain Society (cartoon by Philipp Aliev, Anna Tchoulak)

person, was conscious of these difficulties. Lunch in Jaffa just north of the Gaza strip and facing their gorgeous beach was a happy interlude.

Nothing was happy about my next visit to Israel. Meeting us at the airport, Professor Bornstein was grim. He drove us into his Tel Aviv hospital and we passed the ER where the assassinated Prime Minister Rabin had been pronounced dead that night. The next evening we visited what has been re-named Rabin Square. We stood where he had stood addressing a crowd of peaceseeking Israelis infiltrated by a single radical armed Jewish zealot. Clusters of mourners were sitting in groups around lighted candles. It is easy to speculate that absent this work of a madman the world might have been spared the nightly television spectacles in January 2009 of innocents lying dead and mutilated in Gaza.

Canada, we must remember, was founded by Samuel Champlain who could compromise, conciliate and regarded vengeance and fighting as an uncivilized and extreme approach to any problem. On one occasion he and an interpreter walked unarmed into an Iroquois fortified encampment to talk with success of a possible French/Iroquois peace that lasted 16 years, until destroyed by the intemperate and uncompromising Cardinal Richelieu. When an occasional and deranged Algonquin or Huron native lost his cool and killed a French settler, Champlain forbade vengeance, arrested the suspect, and called the chiefs together to agree upon suitable punishment. Torture and use of force he frowned upon. He had seen its uselessness when growing up during the Catholic/Protestant religious wars in his native France. Our world has never had enough Champlain's. Ironically early in his time in Canada this avant-garde thinker had a stone-age weapon (an arrow) fired (better to say "propelled") at him from an Iroquois bow. His ear was pierced, his face grazed and the record in his definitive biography indicated that the stone tip of the arrow stopped in his neck millimeters from his carotid artery. ${ }^{24}$ (Figure 2)

\section{Anecdote 7}

In the late 1970's we were called upon by the then Director of National Institutes of Neurological Disease and Stroke (NINDS) (Donald Tower) to conduct a randomized trial to determine if there was or was not virtue in the claims that in certain patients threatening with a stroke, worsening of the disability or a further stroke would occur less frequently if the blood to the brain was supplemented by blood from the scalp. The surgery was delicate, done through a small hole drilled in the skull, under an operating microscope and the sutures joining the scalp arteries to those on the surface of the brain were about the size of a human hair. For the operating neurosurgeon it was delicate, challenging and required practice sessions on rodents' arteries. We scoured the academic centres of North America and Europe, with the aid of Murray Goldstein, the new Director of the NINDS to find an adequate number of surgeons skilled in the procedure who were willing to submit the appropriate patients to a double-blind randomized trial in sufficient numbers to get a robust answer to the hypothesis about efficacy, within the limits of reasonable surgical complications, and to complete the study within a reasonable period of time.

After a number of months we realized that for patients with threatening disease from lesions located in the neck we would reach our predicted numbers goal, but not so if the disease was intracranial. We were granted permission to extend the trial to Japan and Taiwan as people with oriental genes have a predilection to occlusive disease of their intracranial arteries c.f. an extracranial predilection in Caucasians. With aggressive assistance from the NINDS we recruited 11 Japanese and Taiwanese centres. Elsewhere our negative benefit results are published and their reluctant acceptance has been covered. ${ }^{24}$ Here I wish to sketch unusual occurrences in each of the countries new to our Trial.

From Taiwan, as a rare treat the visitors, which included Bill Fields, Jim Toole, me and our wives, entered by the rear paratroop exit, an early World War II vintage two-propellorengine paratroop transport. We sat with no seat-belts facing each other on benches parallel to the fuselage on each side. Our destination was the island of Chinmen on the west side of Taiwan Straight and about one mile off the coast of mainland China. There the retreating and so far defeated army of Chiang Kai Chek had been able to hold at bay the huge onslaught of Mao's victorious army while the remnant of the Chiang troops were fleeing to Taiwan. Despite constant shelling from China, fleeing troops dug in and survived. The shelling dropped from daily to irregularly, then to a fixed pre-announced hourly event each day and finally stopped altogether. By this time the army's lives were being lived entirely underground in a series of connected tunnels blasted out of the rock of the mountain. In the rock they hollowed out rooms to billet an army, shopping areas and a large theatre for movies, meetings, etc. A special lunch was served for 
the visitors (allowed only as a rare privilege) in the Officers' Lounge. Our host was the General in charge of this whole operation. Constantly he made reference to the imminent return of his army to re-conquer China from this base just offshore. Although we repeatedly toasted it in some Chinese version of sake, we never believed it was other than a contrived moralebooster for troops posted on a lonely island. Back in Taipei, our host and neurologist in charge of the Bypass Study in Taiwan, Willis Wong, offered to take us to a restaurant that served snake and dog-meat. Instead we settled for Peking duck in the Grand Hotel, built on a hill overlooking Taipei owned by Madame Chiang and probably the most eye-catching hotel that I know, with its massive red lacquered pillars, green facade and gold trim. A striking contrast to the rock caves of Chinmen!

From the Taiwan airport we were rushed out 30 minutes ahead of schedule because of the approach of a "cyclone" (the Pacific term for what would be a" hurricane" over the Atlantic). As we were leaving the terminal's crews were covering the plateglass window with huge fitted sheets of plywood. This was not a new phenomenon on Taiwan. Two days later, I went birdwatching in a forest outside Akita in Japan with Professor Kutzazawa (The Director of the Akita Brain Research Institute and the author of a short guide to the birds of Akita prefecture.) The edge of the cyclone was passing through and for the first time in my life I was hurled off my feet by a particularly sharp gust of wind. I was busy concentrating on a flock of migrating swallows. Both the species and the fall on my face and binoculars were new to me. As Kenji Nakajima muttered as he dusted me off, "not very polite wind for our visitors to Japan" Kay had stayed upright.

Humans remain fascinated by natural phenomena and the fascination increases with the ferocity of nature's uncontrollable attack. Another visit to Akita to fulfill my new annual duties as Honorary President of the Research Institute, had followed an earthquake centred 25 miles to the north-west in the Sea of Japan. A teacher demonstrating marine life in tidal pools had taken his students to higher ground but then miscalculated and came back to the beach just before the delayed Tsunami struck, wiping out the entire class. The earthquake had left cracks and modest destruction in the city. I enquired of what I would do if a major after-shock struck. "Get under the bed or stand in the doorway to the bathroom." In the middle of the night I thought I was having a rigor but soon realized that more than me was shaking. Leaping from bed I detected that it was built down to the floor. The alternative led me to the archway into the bathroom. The shaking continued and I could see the water moving back and forth in the lavatory. As both subsided and then stopped I again took two pillows over my uppermost ear and slept the rest of the night.

\section{Anecdote 8}

The Bypass Study as we came to call it, eventually took nine years, involved 77 centres on three continents and cost the NINDS \$9 million. Because we sought a scrupulous data-base our budget allowed for the employment of professional and experienced staff (mostly nurse practitioners) who would scrutinize every entry and follow-up document for completeness, accuracy and timeliness. Any need for more studies to affirm the cause of a stroke were noted. All problems were shared with the stroke research fellows and brought forward to the Central Office staff at weekly meetings. Irregularities as well as errors crept in and the more serious ones were due usually to slovenly work and once to deliberate cheating. Had they not been identified they could have distorted our results. An example of rare slovenly work is as follows: One of our participating centres was chronically late in submitting follow-up forms. As a Monitoring Committee meeting was due I asked the Study Manager to phone two patients at their homes and to learn if either had experienced a stroke. By a strange coincidence the Study Manager made two calls and reached two patients' widows learning that both had been dead preceding the last form which had been forged in both cases by an indolent junior staff person. When I alerted this young man's professor the result was his dismissal and transfer of our study patients to the care of the professor.

The single example of an attempt to sway deliberately our study to be slanted to favor of surgery was taken by a European collaborator. He was an enthusiast for the unproven procedure. Early in his participation in the Trial he had dismissed his centre neurologist thereby breaking our rule of combined surveillance. In addition the document check at the central office repeatedly portrayed incongruity between the short written description of an event compared to the details in the check-off part of our more searching sheets. This led us to look at the centre's 35 forms randomly assigned "surgery" and the equal number assigned "best medical care." No strokes were recorded in the surgical arm but a dozen in the medical patients. By phone two choices were offered to the miscreant:" 1.) You may call in all your patients to be reviewed by a colleague of my choosing from a separate German centre and I will attend with him and you at the first review clinic. 2.) Your centre will be named as "unreliable"; all your data will be deleted and this publicly declared at the time of our first publication. He accepted the review. Three of us converged on his clinic for the first six patient review. Luckily he spoke perfect English (learned in POW camp in northern Ontario from 1939-1945 as a prisoner taken from his merchant vessel in Halifax on the first day of WW II). He resolutely denied the stroke that had been falsely reported. Over the weeks ahead the altered documents were all corrected and kept in order to the end of the study. Years later this tortured young surgeon and I met at an unrelated meeting in Europe. He approached me, bowed his head, (clicked his heels) held out his hand and murmured softy: "Will you not forgive me?" I gave him a warm handshake and said that I did. We never met again.

\section{Anecdote 9}

To keep up enthusiasm for each of our international, intercontinental and interdisciplinary trials we met annually with all collaborators from each continent in a central place of their choice. One famous time the Australians selected the new hotel at Ayer's Rock in the very heart of Australia's central desert. This red sand-stone monolithic mountain stands by itself. It has been a challenge for decades for non-professional climbers to tackle the path upward. It is sufficiently steep at the start that a sturdy chain has been provided for the initial 250 yards. A few hundred yards beyond this is a narrowing of the trail to less than six feet and steep sides drop down on each side of this part of the trek. Over the years this narrow spot has led some careless adventurers to fall to their death below. Painted footprints now 
mark where the climbers should place their feet. There is always a wind but when excessive or in rain the Aboriginal owners to whom the mountain is sacred close the trail. Without doubt this reduces the number and frequency of memorial brass plaques attached to the Rock at the bottom. We were told some had heart attacks, most just slipped and fell.

The circulated agenda for our two day meeting contained as its first item "6:30 am assemble in running shoes at base of Ayer's Rock. Bus leaves hotel at 6:00 am. All but 2 of 45 registrants set off, only 2 quit before the top. As the oldest on the climb (75 years), Bill Carroll from Perth Australia stayed with me to the top where we had a hearty handshake! A surfeit of endorphins made for an exhilarating Australian Collaborators Meeting.

\section{Anecdote 10}

It is easy to be fascinated with the phenomenon of cataplexy. In its "normal" form it consists of laughing until your legs get weak or you fall off your chair. My first probable encounter with it was at the East General Hospital which had offered three meals and a bed to four of us during our penultimate medical year in return for screening patients in the ER etc. One evening one of our group came to our quarters to report that he had followed a pretty nurse into the corner cupboard on the third floor and had boldly greeted her with a kiss! He reported that she slipped to the floor fully conscious, saying nothing but with her attractive eyes wide open. The rest of us to our everlasting shame tried but failed to confirm this observation during the coming week. Maybe as budding scientists we had learned that single observations must be verifiable.

This curious phenomenon remained a mystery until in our final year we had a lecture on the mid-brain inhibitory syndrome of "Narcolepsy, Cataplexy, Sleep Paralysis and Hypnogogic Hallucinations". My first real clinical encounter with the syndrome including Cataplexy occurred when taking the history of a World War I veteran at the newly-built Sunnybrook Hospital. When asked about past illnesses he unexpectedly volunteered that he had Cataplexy, and yes, he had experienced the related expressions of the disorder and recited their proper names. "Sir if it were not for a medical officer being familiar with the condition I would have been shot by a firing squad as punishment for 'desertion.'" At Ypres his platoon had been ordered "over the top" to face the German machine guns. Instead the Military Police found him lying on his back, conscious with his eyes open. Court-Marshal declared him a deserter, lectured him on cowardice (in the face of probable impending death) but extended to him the courtesy (not always feasible) of a preexecution medical examination. (A pity to execute a sick person according to the twisted army regulations of the day.) All that he now faced was medical discharge, a full life ahead in the country that had presented him with an unusually astute RCAMC Captain who had taken the trouble to read the fine print in his text books. Because this scenario all developed in the mud and chaos of 32 years from my encounter with him, I shared his wish that whatever if any afterlife is accorded good doctors we both hope he got his share.

Emotional excitement triggers cataplexy. My last encounter with it was a perfect example. A rooky policeman had cornered a villain in a back alley and was reaching for his pistol to ensure obedience. To his embarrassment he had his first cataplectic fall and watched the rogue climb the fence to undeserved freedom.

\section{Anecdote 11}

Physicians are privileged to meet people prominent in their communities but also from a wider catchment basin. I will confine this anecdote to the local ones. While still in Toronto I was phoned from the exclusive and haughty York Club to say that a very prominent financier (let us call him Patient A) had suffered a stroke and was on his way to the hospital. As was custom in those early days I was obliged to perform the directpuncture carotid arteriogram. This revealed a very tight narrowing of the appropriate carotid artery in the neck and Bill Lougheed performed one of Canada's first carotid endarterectomies. As bad luck would have it and whilst Bay Street colleagues (and competitors) and York Club members awaited the good word of his recovery, he remained confused post-operatively to the extreme concern of family, friends and care-givers. Then rather quickly on the fourth day he was well again with no evidence of confusion or stroke. As we had hopefully speculated he was one of the $1 \%$ or so whose brain reacted diffusely and temporarily to the contrast material used at that time to make the pictures. A few years later a prosperous country neighbor who lived modestly, (let us call him Patient B) had returned by air evacuation from a Mexico vacation with a sudden headache and speech loss. He proved to have a small frontal lobar hemorrhage centred in the speech area. With careful blood pressure management he recovered except for a lifetime of reading difficulty ahead. I imbued him, as I did so many acquaintances with a fondness for bird-watching. One day after a morning hike we breakfasted at my house. I was at the time seeking funding to send a young neurologist from Atlanta to study with an immunology expert in Newcastle-on-Tyne so that he (Don Paty) might start our Multiple Sclerosis Research team. Funding for training an American to come back to Canada encountered many barriers. Brazenly at breakfast I suggested to Patient B (Mathew Heron) that I was thinking of asking Patient A to give us two years' salary and travelling expenses. Mathew kept his head down for a minute (and it seemed longer). I began to think that he thought it presumptuous of me to impose on a friend and former patient in this way. Suddenly he raised his head and with a broad smile on his face: "Barney why don't you ask me for this money"? We did and it transpired that in a few years we had four experts in the study and therapy of patients with multiple sclerosis who found themselves caring for the largest patient research clinic anywhere devoted to this disorder. Their expertise over the years became divided between Vancouver, Mayo Clinic, Oxford and London Ontario. Mathew's investment was not in vain! To add to his largesse he funded the development and growth of the neuroscience library in the University Hospital.

Half a mile up the Concession Road from Mathew lived Gage Love. He was the first person I knew who loved to make money so that he could give it away. His grandfather launched the National Tuberculosis (T.B.) Association, started the Weston T.B. Sanatorium, the Gage Institute and the Muskoka Sanatorium. Philanthropy was bred in Gage's bones. When TB was reduced to the point of no longer needing separate hospitals, 
Gage sold the Muskoka San and used the money plus some of his own to convert the Weston San into one of the area's best rehabilitation hospitals (West Park Hospital.) The Gage Institute was donated to the University of Toronto as a pulmonary disease research unit. Gage disliked show and pretension. He taught me Emerson's thinking on the subject: "Pretension never drove back Xerxes, pretension never wrote an Iliad, - pretension never freed the slaves." I was proud to share grandchildren with this remarkable man because his \#2 boy married our \#1 girl and they have shared their lives together for nearly half a century.

Beryl and Dick Ivey were the London counterpart of Gage Love. Dick's father left a Foundation in his stewardship. From this endowment of close to one million dollars over the years the Ivey Foundation have delighted in giving away close to 100 times this original sum. Nothing in science, business, the arts or the environment in Western Ontario has escaped their generous support. Their promise to Charles Drake that they would be supportive of the development of a new University of Western Ontario Department devoted to the nervous system took me to London. In due course I followed our plan for a rotating chairmanship and became the Richard and Jean Ivey Chairman of this novel (for Canada) interdisciplinary clinical department. The heads of Medicine and Surgery, Ramsay Gunton and Angus McLachlan, respectively, had to relinquish their control of the divisions of neurology and neurosurgery. I am forever grateful to them and to successive Deans Warwick and Bocking for their acceptance of this radical change. True to their word the Ivey Foundation has continued to be aggressively promotional of this new Department, as it has been of the growth of the innovative inter-disciplinary Robarts Research Institute, which Charles Drake and I also conceived and founded.

London Ontario had a unique collection of successful business men and women who have taken an exceptional interest in supporting medical care and research. This included J. Allyn Taylor, Walter Blackburn, Jack Stevens, Don Smith, Phil Bowman, Bill Brady, Darcy McKeough, Don McGeachy and a host of others.

\section{REFERENCES}

1. Barnett HJM. Reflections on aspects of medical progress. 19442008 - Part 1. Can J Neurol Sci. 2009;36:6-13.

2. Barnett HJM. Personal reflections from a front-row seat at the greatest show on earth (life): Part II (stroke research commentary). Stroke. 2009;40:e53-e65.

3. Barnett HJM, Botterell EH, Jousse AT, Wynne-Jones MW. Progressive myelopathy as a sequel to traumatic paraplegia. Med Serv J. Can. 1966;22(7):631-50.

4. Barnett HJM, Jousse AT. Posttraumatic syringomyelia (cystic myelopathy). In: Vinken PJ, Bruyn GW, editors. Handbook of clinical neurology. 1976. p. 113-57.

5. Gent M, Barnett HJM, Sackett DL, Taylor DW. A randomized trial of aspirin and sulfinpirazone in patients with threatened stroke: results and methodological issues. Circulation. 1980;62 Suppl V: V97-105.

6. The Canadian Cooperative Study Group. A randomized trial of aspirin and sulfinpyrazone in threatened stroke. N Engl J Med. 1978;299:53-9.

7. Barnett HJM, Boughner DR, Taylor W, Cooper PE, Kostuk WJ, Nichol PE. Further evidence relating mitral valve prolapse to cerebral ischemic events. N Engl J Med. 1980;302:139-44.

8. Avierinos JF, Brown RD, Foley DA, Nkomo V, Petty GW, Scott C, et al. Cerebral ischemic events after diagnosis of mitral valve prolapse: a community-based study of incidence and predictive factors. Stroke. 2003;34:1339-44.
9. Barnett HJM. Delayed ischemic events distal to occlusion of major cerebral arteries. Neurology. 1978;28:769-74.

10. Barnett HJM, Peerless SJ, Kaufmann JCE. "Stump" of internal carotid artery, a source for further cerebral embolic ischemia. Stroke. 1978;9:448-56.

11. The EC-/IC Bypass Study Group. Failure of extracranial-intracranial arterial bypass to reduce the risk of ischemic stroke. N Engl J Med. 1985;313:1191-200.

12. NASCET Collaborators. Beneficial affect of endarterectomy in symptomatic patients with high-grade carotid stenosis. N Engl J Med. 1991;325:445-53.

13. Fox AJ, Eliasziw M, Rothwell PM, Schmidt MH, Warlow CP, Barnett HJM. Identification, prognosis, and management of patients with carotid artery near-occlusion. AJNR Am J Neuroradiol. 2006;26:2086-94.

14. Barnett HJM, Taylor DW, Eliasziw M, Fox A, Ferguson GG, Haynes RB, et al for the North Am Symptomatic Carotid Endarterectomy Trial Collaborators. Benefit of carotid endarterectomy in patients with symptomatic moderate or severe stenosis. N Engl J Med. 1998;339:1415-25.

15. Alamowitch S, Eliasziw M, Barnett HJM, North American Symptomatic Carotid Endarterectomy Trial (NASCET); ASA Trial Group. Carotid Endarterectomy (ACE) Trial Group. The risk and benefit of carotid endarterectomy in women with symptomatic internal carotid artery disease. Stroke. 2005;36: 27-31.

16. Benavente O, Eliasziw M, Streifler JY, Fox AJ, Barnett HJM, Meldrum H. North American Symptomatic Carotid Endarterectomy Trial Collaborators. Prognosis after transient monocular blindness associated with carotid artery stenosis. N Engl J Med. 2001;345:1084-90.

17. Alamowitch S, Eliasziw M, Aigra A, Meldrum H, Barnett HJM. North American Symptomatic Carotid Endarterectomy Trial (NASCET) Group. Risks, causes and prevention of ischemic stroke in elderly patients with symptomatic internal carotid artery stenosis. Lancet. 2001;357:1154-60.

18. Executive Committee for the Asymptomatic Carotid Atherosclerosis Study. Endarterectomy for asymptomatic carotid artery stenosis. JAMA. 1995;273:1421-8.

19. Halliday A, Mansfield A, Marro J, Peto C, Peto R, Potter J, et al. MRC Asymptomatic Carotid Surgery trial (ACST) Collaborative Group. Prevention of disabling and fatal strokes by successful carotid endarterectomy in patients without recent neurological symptoms: randomized controlled trial. Lancet. 2004;363: 1491-502.

20. Eliasziw M, AJ Fox, BL Sharpe, HJM Barnett. Carotid artery stenosis: external validity of the North American symptomatic carotid endarterectomy trial measuremant method. Radiology. 1997;204:229-33.

21. Eliasziw M, Smith RF, Holdworth DW, Fox AJ, Barnett HJM for the NASCET Group. Further comments on the measurement of carotid stenosis from angiograms. Stroke. 1994;25:2445-9.

22. Barnett HJM. Reflections on the carotid artery: the Karolinska award lecture. Stroke. 2009;40:3143-8.

23. Barnett HJM, Meldrum H. Reflections on the conduct of multicenter stroke trials. In: Barnett HJM, Bogousslavsky J, Meldrum H, editors. Advances in neurology. Volume 92. New York: Lippincott, Williams \& Wilkins; 2003. p. 241-7.

24. Fischer DH, Champlain's dream. New York, NY: Alfred A Knopf; 2008. p. 278 